\title{
Pharmacological Aspects of the Chemotherapy of Leprosy
}

\author{
G. A. ELLARD \\ MRC Unit for Laboratory Studies of Tuberculosis, Royal Postgraduate Medical School, \\ Ducane Road, London W12 OHS
}

\begin{abstract}
Pharmacological and bacteriological aspects of the treatment of lepromatous leprosy with dapsone, rifampicin, clofazimine, acedapsone, long-acting sulphonamides, thiacetazone, thiambutosine and other diphenyl thioureas are considered, and the problem of preventing lepromatous patients ultimately relapsing with drug-resistant strains of Myco. leprae is discussed.
\end{abstract}

The chemical structures of the most important antileprosy drugs are shown in Fig. 1, together with their minimal inhibitory concentrations (MICs) against Myco. leprae as determined using the mouse footpad model. The part of each molecule that appears essential for antileprosy activity is shown in heavier type. Dapsone (DDS) is by far the most active antileprosy drug known, with an MIC against Myco. leprae of only about $0.003 \mu \mathrm{g} / \mathrm{ml}$ (Ellard et al., 1971; Ozawa et al., 1971; Peters et al., 1972). Although other sulphonamides such as șulphadimethoxine and sulphadoxine are also active, their antileprosy activity is only about a 10,000th of that of DDS (Ellard et al., 1970). Acedapsone or diacetyl-DDS (DADDS) is almost certainly devoid of intrinsic antileprosy activity, but is active in vivo because it is deacetylated by the body to DDS (Glazko et al., 1968; Ozawa et al., 1971; Russell et al., 1973). Rifampicin is a semisynthetic antibiotic whose synthetic side-chain is not essential for antimycobacterial activity, but conveys important pharmacological properties on the drug. Its MIC against Myco. leprae (Holmes and Hilson, 1972) is similar to that against Myco. tuberculosis. Although the minimal effective doses of thiambutosine, thiocarlide and thiacetazone required to prevent the multiplication of Myco. leprae in the mouse have been determined recently (Personal communication, M. J. Colston), their MICs against Myco. leprae have still to be established. The MIC of clofazimine against Myco. leprae cannot be determined because of its uneven tissue distribution (Banerjee et al., 1974; Levy, 1974). Although it is highly probable that other sulphonamides will be found with significant antileprosy activity, it is very unlikely that another member of this group of compounds will be found with activity comparable to that of DDS. There is however no reason why other diphenyl thioureas with greater antileprosy activity than either thiambutosine or thiocarlide might not be found, or a more potent thiosemcarbazide than thiacetazone.

For an antileprosy drug to be effective in man, well-tolerated doses must produce tissue concentrations that at least temporarily exceed its MIC against Myco. leprae. The administration of each successive dose to a patient results in some viable drug-sensitive leprosy bacilli being killed and in others ceasing to 
multiply. The relative importance of these two effects depends on whether the drug is primarily bactericidal or bacteriostatic. Rifampicin is primarily a bactericidal drug, but all the other antileprosy drugs appear to be basically bacteriostatic. The chief reasons for therapeutic failure when bacteriostatic drugs are used are probably irregular dosage, which results in drug concentrations falling below their MIC against Myco. leprae for an appreciable length of time and so enables a significant number of leprosy bacilli to multiply between doses, and relapse caused by the appearance of drug-resistant Myco. leprae. Hence one might anticipate that the relative efficacy of different bacteriostatic drugs in the treatment of human leprosy is related both to the duration in which concentrations greater than the MIC are maintained after giving well-tolerated doses of the drugs, and to the ratios of peak drug concentrations to the MIC. The attainment of high peak drug concentrations would however be much less important if combined treatment were being employed to minimize the likelihood of ultimate relapse with drug-resistant leprosy.

Experimental studies have demonstrated the excellent tissue penetration of DDS and rifampicin (Francis, 1953; Shepard and Chang, 1964; Keberle et al., 1968; Murray et al., 1974; Weddell et al., 1975) and it is therefore reasonable to assume that tissue concentrations of most antileprosy drugs probably parallel their serum levels. Approximate estimates of the ratio of the peak serum concentrations to their MICs against Myco. leprae and the durations of coverage achieved with well-tolerated doses of the most widely used antileprosy drugs are summarized in Table 1. Dapsone, the 2 long-acting sulphonamides, rifampicin and

TABLE 1

Absorption, peak concentrations and durations of coverage achieved with welltolerated doses of antileprosy drugs

\begin{tabular}{|c|c|c|c|c|}
\hline Drug & $\begin{array}{l}\text { Dose } \\
(\mathrm{mg})\end{array}$ & $\begin{array}{l}\text { Percentage dose } \\
\text { absorbed }\end{array}$ & $\begin{array}{l}\text { Ratio peak serum } \\
\text { concentration to MIC } \\
\text { against Myco. leprae }\end{array}$ & $\begin{array}{c}\text { Duration serum } \\
\text { concentrations greater } \\
\text { than MIC (days) }\end{array}$ \\
\hline Dapsone & 50 & $>90$ & 300 & 10 \\
\hline Sulphadimethoxine & 1500 & $>90$ & 7 & 4 \\
\hline Sulphadoxine & 1500 & $>90$ & 4 & 14 \\
\hline Acedapsone & 225 & 100 & 16 & 200 \\
\hline Rifampicin ${ }^{a}$ & 600 & $>90$ & 30 & 1 \\
\hline Clofazimine & 300 & $<50$ &.- & - \\
\hline Thiambutosine & 1500 & 10 & - & $?<2$ \\
\hline Thiocarlide & 2000 & 2 & .- & $?<2$ \\
\hline Thiacetazone & 150 & $>90$ & - & $?<2$ \\
\hline
\end{tabular}

${ }^{a}$ Primarily a bactericidal drug; all other drugs basically bacteriostatic.

thiacetazone are all well absorbed (Keberle et al., 1968; Israeli et al., 1973; Ellard et al., 1974). Clofazimine, thiambutosine and thiocarlide are much less watersoluble than the other drugs and are poorly absorbed in man. The extent of the absorption of clofazimine in man is very difficult to determine (Banerjee et al., 1974), but there is conclusive evidence concerning the poor absorption of the diphenyl thioureas thiambutosine and thiocarlide (Ellard and Naylor, 1961; Emerson and Nicholson, 1965).

When considered from these points of view, the antileprosy activity of dapsone clearly surpasses that of all the other bacteriostatic drugs. Thus giving a single 
dose of $50 \mathrm{mg}$ DDS results in peak serum concentrations of approximately 300 times its MIC against Myco. leprae and coverage for about 10 days. By contrast much less adequate levels of antileprosy activity are attainable with the long-acting sulphonamides sulphadimethoxine and sulphadoxine and there is therefore no justification for continuing to use these drugs for the treatment of leprosy. The use of other sulphonamides would also appear unwarranted, at least until their MICs against Myco. leprae have been definitively established using the mouse footpad system. Acedapsone (DADDS) is without doubt the long-acting preparation of choice since a single intramuscular injection of $225 \mathrm{mg}$ gives peak DDS plasma concentrations about 16 times the MIC against Myco. leprae and concentrations of greater than the MIC are maintained for about 200 days. Because the MICs of clofazimine, thiambutosine, thiocarlide and thiacetazone against Myco. leprae are not known, similar calculations are not possible for these drugs. However, from what is known of the pharmacology of the last 3 drugs in man, it is probable that bacteriostatic concentrations of these drugs are only maintained for between 1 and 2 days after giving single doses. By contrast it is possible that active concentrations of clofazimine, which is accumulated in a most remarkable way by the reticulo-endothelial system, may only be achieved after several weeks of treatment, although they may then be maintained for several weeks after stopping dosage at the end of a lengthy period of treatment.

The results of treating lepromatous patients with single drugs (monotherapy) for periods of up to 5 years will now be considered. It must be emphasized that the bacteriological assumptions on which Figs 2-5 are based are necessarily at the

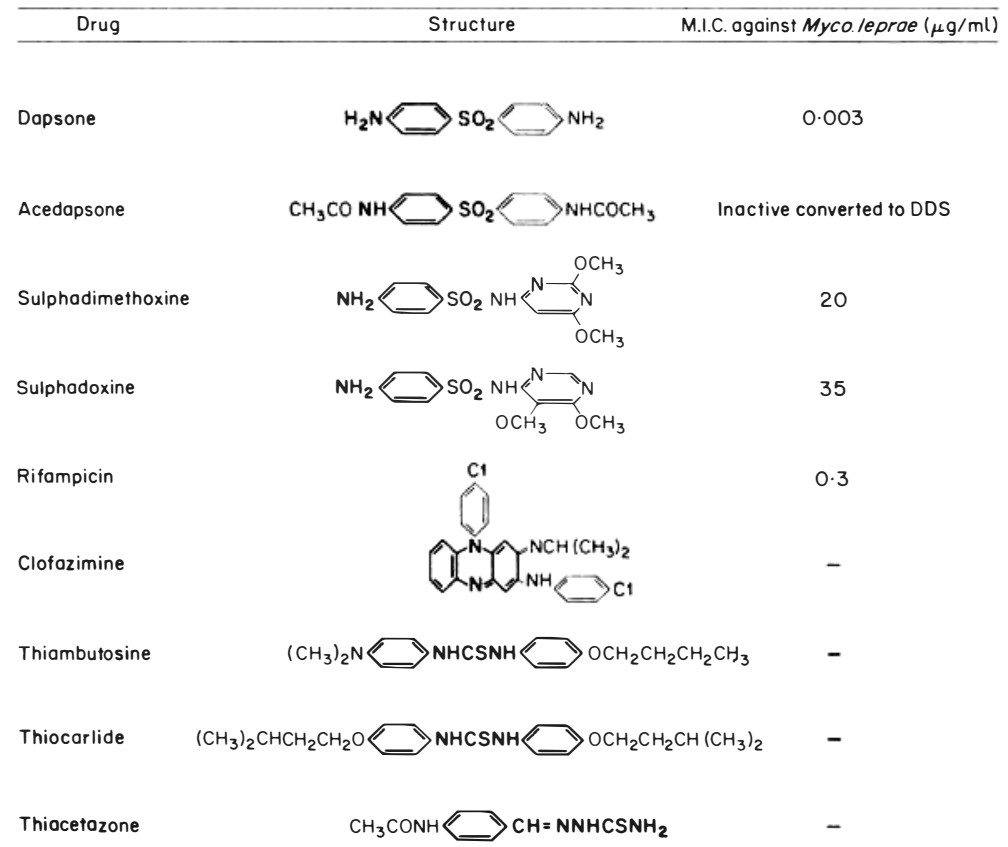

Fig. 1. Structure and minimal inhibitory concentrations of antileprosy drugs. 
best only reasonable guesses, since there is at present no data available to enable one to predict reliably either the total numbers of dead or viable leprosy bacilli, or the numbers or proportions of naturally drug-resistant mutants of Myco. leprae that would be likely to be present in a leprosy patient prior to treatment, or the actual degrees of resistance of such mutants.

When lepromatous patients are treated with daily doses of thiambutosine, thiocarlide, other diphenyl thioureas, or thiacetazone, an initial favourable response is seen which is similar to that encountered when DDS is given. However after 2-4 years treatment relapses occur due to the appearance of drug-resistant Myco. leprae (Lowe, 1954; Davey, 1960; Quyen et al., 1960; Rees, 1967a,b; Garrod and Ellard, 1968). Possible changes in the total body population of Myco. leprae in a lepromatous patient treated with one of these drugs are outlined in Fig. 2. In the bacteriological model used to draw up the figure it has been

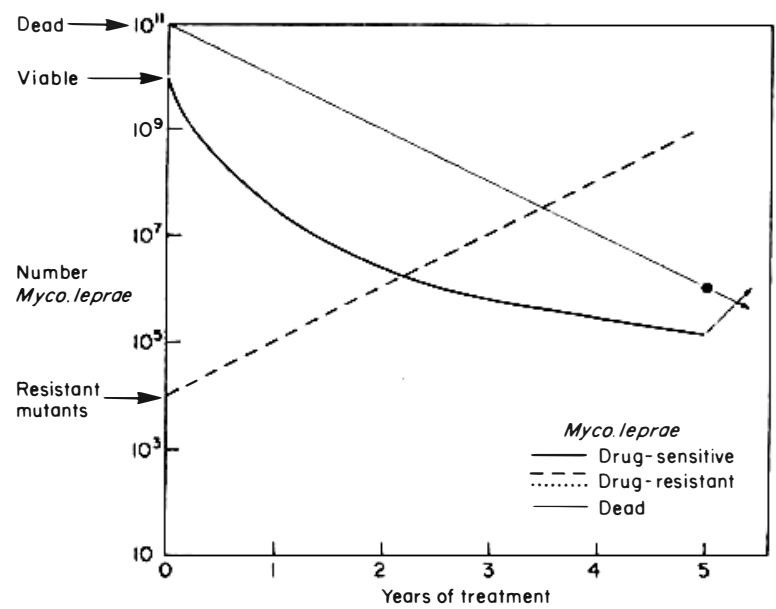

Fig. 2. Possible changes in numbers of Myco. leprae in a lepromatous patient treated with thiambutosine, thiocarlide or thiacetazone.

assumed that prior to treatment such a patient might harbour a population of the order of $10^{10}$ viable leprosy bacilli, of which $10^{4}\left(1\right.$ in $\left.10^{6}\right)$ might be naturally resistant to these drugs, as well as some $10^{11}$ dead Myco. leprae. Daily treatment with thiambutosine, thiocarlide or thiacetazone would not be expected to kill a significant proportion of viable leprosy bacilli as these drugs are primarily bacteriostatic, but should prevent the further growth of most of the drug-sensitive leprosy bacilli. The number of viable Myco. leprae would then be expected to fall slowly as a result of killing by the very limited cell-mediated immune response manifested against Myco. leprae. The drug-resistant mutants would however continue to multiply until both bacteriological and clinical relapse became apparent.

The results that might be anticipated when such a lepromatous patient is treated with $225 \mathrm{mg}$ DADDS intramuscularly every $2 \frac{1}{2}$ months or with $50 \mathrm{mg}$ oral DDS daily are illustrated in Fig. 3. The results expected with low dosage DDS treatment or by giving DDS derivatives such as sulphetrone or promin would be intermediate between those shown for DADDS and DDS. Treatment with 


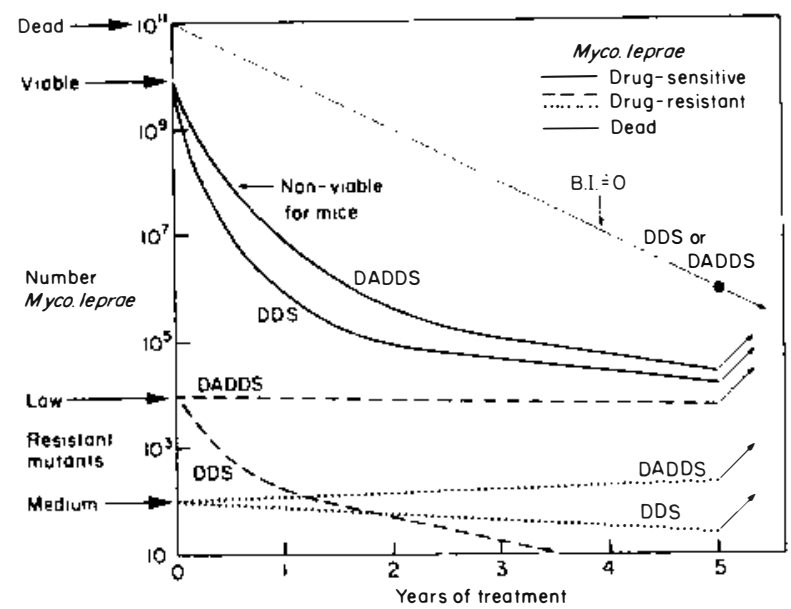

Fig. 3. Possible changes in numbers of Myco. leprae in a lepromatous patient treated with DDS or DADDS.

DADDS results in the numbers of viable Myco. leprae falling about a hundred-fold in about 6 months (3-9 months), since at this point inocula are no longer infective for mice (Shepard et al., 1972). The same workers showed that when patients are treated with DDS the numbers of viable Myco. leprae fall more rapidly, inocula usually becoming non-infectious for mice within about 3 months treatment. These findings suggest that the continuous presence of DDS concentrations vastly in excess of its MIC against Myco. leprae results in DDS being partially bactericidal. Such bactericidal activity would only be expected to be displayed against a small proportion of actively growing bacilli (Then and Angehern, 1973), and against the great majority of leprosy bacilli all concentrations of DDS would probably be primarily bacteriostatic. Giving either DADDS or DDS should prevent the growth of all drug-sensitive leprosy bacilli and after the first few months of treatment the rate of elimination of Myco. leprae might well be similar whichever drug was given and depend principally on the extent of the cell-mediated immune response of the patient to Myco. leprae.

Mutants with varying degrees of resistance to DDS have been isolated from patients after prolonged treatment with DDS or other sulphones (Rees, 1967a; Pearson et al., 1968; Shepard et al., 1969a). In the extremely simplistic model used as a basis for Fig. 3 it was assumed that prior to treatment there were $10^{4}$ viable leprosy bacilli $\left(1\right.$ in $10^{6}$ ) resistant to 10 times the normal MIC of DDS against sensitive bacilli and 100 bacilli ( 1 in $10^{8}$ ) resistant to 100 times this value. Treatment with high dosage DDS might still be expected to result in the killing significant numbers of actively-growing low-resistant mutants and to result in their elimination within 3-4 years. By contrast DADDS treatment would be purely bacteriostatic since it would result in DDS levels only slightly above the MICs of the mutants. Furthermore such DDS concentrations would be incapable of preventing the growth of mutants with medium resistance whereas their growth would still be prevented by high dosage DDS treatment.

The changes in bacterial populations of sensitive and drug-resistant Myco. leprae illustrated in Fig. 3 have been drawn up to take account of the length of 
persistence of DDS-sensitive bacilli during treatment with high dosage DDS (Waters et al., 1974), the long periods before drug-resistance becomes apparent (Meade et al., 1973), the higher incidence of resistance and earlier occurrence of resistance after treatment with low dose DDS regimens, and the tendency of resistance encountered with such regimens to be of a lower level than when high dosage DDS treatment is employed (Meade et al., 1973; Personal communication J. M. H. Pearson and R. J. W. Rees). Alternative bacteriological models could however also explain such findings. Thus it is possible that there may be initially only mutants with low degrees of DDS resistance and that mutants with higher degrees of resistance only arise as the result of a series of further mutations.

Whichever model one considers, one would expect continued treatment to result in the gradual selection of DDS-resistant mutants, regular treatment with high dosage DDS to be the most successful form of monotherapy, and irregular treatment with low dosage DDS to be most likely to lead to relapse occurring with the appearance of DDS-resistant Myco. leprae.

The fall in numbers of viable bacilli obtained during treatment with clofazimine is intermediate between the results obtained with DADDS and DDS. The fact that clofazimine-resistant strains of Myco. leprae have not yet been isolated suggests that the frequency of initially resistant mutants is probably less than that encountered with thiambutosine or thiacetazone. The possibility that long term treatment with clofazimine alone will also result in patients relapsing with drug-resistant Myco. leprae must however always be borne in mind.

The results that might be anticipated when a lepromatous patient is treated with $600 \mathrm{mg}$ rifampicin a day are illustrated in Fig. 4. Several studies have shown

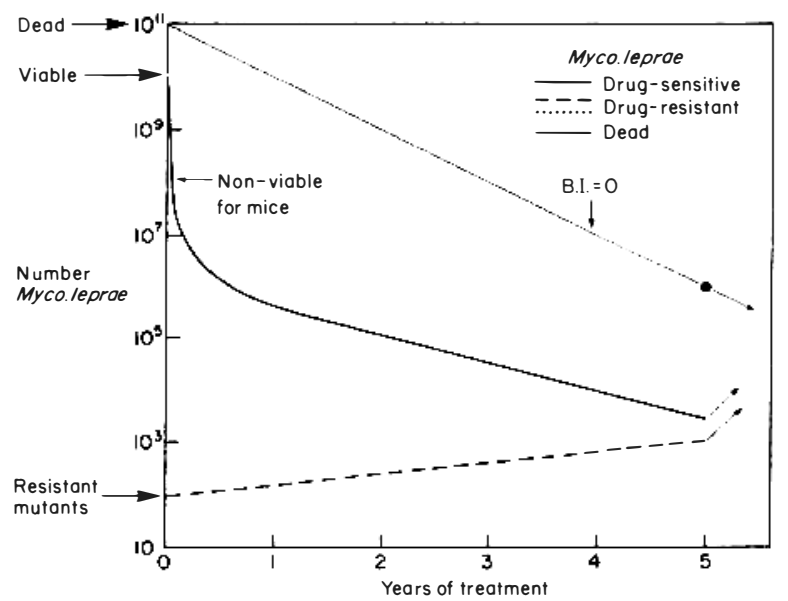

Fig. 4. Possible changes in numbers of Myco. leprae in a lepromatous patient treated with rifampicin.

that such treatment results in inocula no longer being infective for mice after as little as a week's treatment, indicating that in this period over $99 \%$ of the viable leprosy have been killed by the drug (Rees et al., 1970; Shepard et al., 1972b, 1974). Rifampicin's powerful bactericidal activity against Myco. leprae parallels that against Myco. tuberculosis. The persistence of viable rifampicin-sensitive 
leprosy bacilli for periods of up to 2 years despite continued daily treatment with rifampicin indicates that a proportion of the bacterial population remain insensitive to its action (Personal communication, R. J. W. Rees and M. F. R. Waters). Again these results parallel findings with Myco. tuberculosis where in vitro studies have shown rifampicin has very little bactericidal activity against non-growing organisms (Dickinson et al., 1972; Awaness et al., 1975). Although no case has yet been reported of a patient relapsing with rifampicin-resistant Myco. leprae, experience in the treatment of tuberculosis suggests that the possibility of this occurring should not be dismissed.

In the past, the most widely employed form of treatment has been monotherapy with DDS or other sulphones. The most important limitations of such treatment are the great length of time required to eliminate all viable $M y c o$ leprae from lepromatous patients (Waters et al., 1974) and the ultimate relapse of a significant proportion of patients with DDS-resistant Myco. leprae (Meade et al., 1973). The most probable causes of relapse appear to be the use of regimens giving relatively lower levels of DDS in the body and interruptions to treatment. The ideal regimen should be fully effective in all types of leprosy patients, should not result in lepromatous patients relapsing with drug-resistant Myco. leprae, should be economical, should be free from adverse side-effects, and should be administratively convenient to supervise. Experience in the chemotherapy of tuberculosis indicates that relapse with drug-resistant organisms can be avoided by using combined chemotherapy. The most effective two-drug regimen that one can envisage at present for the treatment of leprosy patients would be to give DDS $(50 \mathrm{mg})$ plus rifampicin $(600 \mathrm{mg})$ each day throughout treatment. The cost of rifampicin however obviously makes such a regimen impracticable for most countries. Long-term treatment with DDS plus clofazimine would probably be unacceptable to many patients because of skin discoloration. From an economic point of view, the most feasible two-drug regimen would probable be DDS $(50 \mathrm{mg})$ plus thiacetazone $(150 \mathrm{mg})$ daily. Unfortunately the adverse side-effects encountered with thiacetazone are such that one could not recommend its long-term use in several areas of the world (Miller et al., 1970).

Practical chemotherapy is necessarily a compromise between efficacy, cost and convenience of administration. The treatment scheme outlined in Fig. 5 represents my attempt to arrive at such a compromise. It employs as its mainstay 2 years supervised daily treatment with high dosage DDS, since DDS is still the most effective economical antileprosy drug available. In the case of lepromatous patients it is suggested that this treatment should be supplemented by the addition of $600 \mathrm{mg}$ rifampicin each day during the first week. Increasing the duration of this rifampicin supplement might well reduce the ultimate chances of subsequent relapse with DDS-resistant Myco. leprae occurring, but it would probably be better to treat a given number of lepromatous patients with a week's rifampicin rather than half the number with a fortnight's supplement. It is then suggested that after the first 2 years, treatment should be based on injections of DADDS every 3 months since this is the most reliable method of ensuring that DDS concentrations greater than the MIC against Myco. leprae are continuously maintained in patients.

Using the same bacteriological model as that employed in drawing up the previous figures, the results obtained with such a treatment scheme might resemble those illustrated in Fig. 5. The first week's treatment under full supervision with $50 \mathrm{mg}$ DDS and $600 \mathrm{mg}$ rifampicin each day should reduce the 


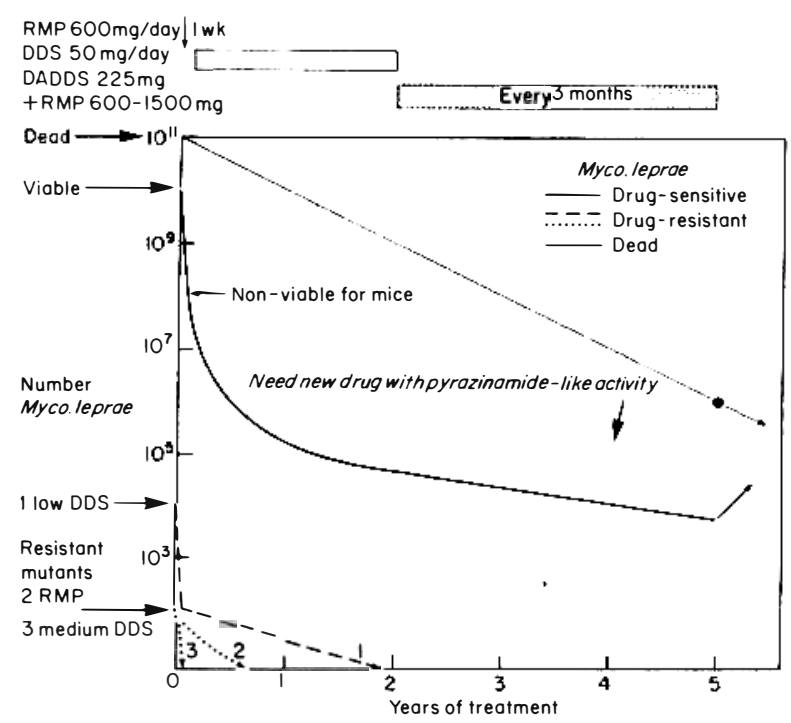

Fig. 5. Possible changes in numbers of Myco. leprae in a lepromatous patient treated with the suggested treatment schedule.

number of viable leprosy bacilli to less than $1 \%$ of their original total and effectively render the patient non-infectious. It should also reduce the number of mutants with low degrees of DDS resistance to a hundredth of their original number, and almost entirely eliminate rarer mutants with higher degrees of DDS resistance. During the subsequent 2 years of supervised high dosage DDS treatment one would hope that the remaining mutants of low degrees of DDS resistance and any rifampicin resistant mutants would be eliminated. During this period in-patients might receive $50 \mathrm{mg}$ DDS daily and out-patients $300 \mathrm{mg}$ DDS once a week. At the end of this period treatment with injections of $225 \mathrm{mg}$ DADDS every 3 months should be sufficient to prevent the growth of the remaining viable Myco. leprae, all of which ought to be fully sensitive to DDS.

In situations where supervision of treatment is impossible to organize, chemotherapy might be based on 3 monthly injections of DADDS, supplemented by supervised dosage with $1500 \mathrm{mg}$ rifampicin once every 3 months as suggested by Shepard and his colleagues (Shepard et al., 1971; Shepard et al., 1972b; Levy et al., 1973), and by giving out at the same time 3 months supply of $50 \mathrm{mg}$ DDS tablets for daily self-administration. Such a schedule should also help to minimize relapses caused by the emergence of DDS-resistant Myco. leprae even if many of the patients failed to take their oral DDS doses regularly (Ellard, et al., 1974).

As has been emphasized previously, the lack of reliable data concerning the number of naturally drug-resistant Myco. leprae that might be anticipated in a lepromatous patient prior to treatment, precludes a proper discussion of the relative merits of different methods of treating patients in such a way as to minimize the likelihood of their ultimately relapsing with drug-resistant Myco. leprae. As a consequence the results of the treatment scheme illustrated in Fig. 5 are speculative. Thus it could be that the principal factor influencing the emergence of DDS resistance is not the number of DDS-resistant mutants present 
at the start of treatment, but rather the extent of multiplication occurring during treatment either because of gross irregularity of drug ingestion or because some multiplication of DDS-sensitive bacilli may be able to occur despite regular DDS treatment. The best method of preventing patients relapsing through the emergence of DDS-resistant strains of Myco. leprae depends on which mechanism is the most important. If, as has been assumed, the number of DDS-resistant mutants present at the start of treatment is the most important factor, then the addition of rifampicin at the start of treatment is likely to be the best supplement to use. If irregularity in drug taking is more important, one should concentrate on improving methods of supervising drug dosage. If however the most important cause of resistance were the ability of a significant proportion of DDS-sensitive leprosy bacilli to multiply despite regular treatment with DDS, one would recommend prolonged treatment with 2 drugs if this were at all possible.

Unfortunately, despite the great advances in recent years in experimental leprosy, the possibility of obtaining the bacteriological data necessary to put such treatment on a sound basis in the foreseeable future is still remote. Therefore the only possible prospective approach to the problem of preventing patients relapsing with DDS-resistant leprosy is to compare the results of different treatment schemes by means of controlled clinical trials. For example if one wanted to evaluate the sort of treatment scheme outlined in Fig. 5, one might compare the results of a treatment scheme without an initial rifampicin supplement, with the same treatment scheme supplemented by either a week or a month of rifampicin treatment. Because of the many years before DDS-resistance becomes apparent and the hundreds of patients that would have to be treated to obtain a statistically significant conclusion, the whole idea of trying to make such a comparison may seem to be utterly daunting. However, as studies in the chemotherapy of tuberculosis have shown, the scope of the controlled clinical trial can be very extensive (Fox, 1971). Thus in a situation where rigid control of treatment of patients over any length of time was completely impractical, one might arrange for all lepromatous patients commencing treatment in an area to be allocated at random to the treatment scheme currently being employed and to the same treatment scheme supplemented in ways that were practical for the area in question. The supplement might consist of the addition of a week's rifampicin at the start of treatment or alternatively of 3 monthly injections of DADDS (with or without large single doses of rifampicin) given over many years. The organisational problems of such an approach are of course formidable for hundreds of patients would need to be studied and their therapeutic response followed for 10-20 years and Myco. leprae would have to be isolated from all patients who appeared to be relapsing and tested in the mouse footpad to establish whether they were DDS-resistant or not (Pettit et al., 1966). Nevertheless, unless such comparisons are made in trials carried out with sufficient numbers of patients, the possibility of finding out whether the emergence of DDS-resistance can be prevented would seem remote.

It must be emphasized that all the approaches discussed so far would not be expected to shorten significantly the period required to cure lepromatous patients since it is apparent that neither DDS nor rifampicin are capable of killing near-dormant organisms with any speed. Among antituberculosis drugs, pyrazinamide appears to possess an almost unique ability in killing semi-dormant bacilli (Fox and Mitchison, 1975). Regrettably the evidence at present available 
suggests that doses of pyrazinamide that are well tolerated in man are inactive against Myco. leprae (Shepard and Chang, 1964; unpublished results G. A. Ellard and M. J. Colston). Whether an analogue of pyrazinamide might be found with significant activity against $M y c o$. leprae remains to be established. If such a compound could be found that was also well tolerated in man, it could conceivably lead to the possibility of curing lepromatous leprosy in a shorter time.

\section{Acknowledgement}

I should like to thank Prof. D. A. Mitchison and Dr R. J. W. Rees for their advice.

\section{References}

Awaness, A. M., Dickinson, J. M. and Mitchison, D. A. (1975). Bactericidal activity of rifampicin and isoniazid against tubercle bacilli. In press.

Banerjee, D. K., Ellard, G. A., Gammon, P. T. and Waters, M. F. R. (1974). Some observations on the pharmacology of clofazimine (B 663). Am. J. trop. Med. Hyg. 23, 1110.

Davey, T. F. (1960). Some recent chemotherapeutic work in leprosy. Trans. R. Soc. trop. Med. Hyg. 54, 199.

Dickinson, J. M., Jackett, P. S. and Mitchison, D. A. (1972). The effect of pulsed exposures of rifampicin on the uptake of uridine $-{ }^{14} \mathrm{C}$ by Mycobacterium tuberculosis. Am. Rev. resp. Dis. $105,519$.

Ellard, G. A., Gammon, P. T. and Harris, J. (1974). The application of urine tests to monitor the regularity of dapsone self-administration. Lepr. Rev. 45, 224.

Ellard, G. A., Gammon, P. T. and Rees, R. J. W. (1970). The minimal inhibitory concentrations of sulphadimethoxine and sulphadoxine against Mycobacterium leprae. Lepr. Rev. 41, 223.

Ellard, G. A., Gammon, P. T., Rees, R. J. W. and Waters, M. F. R. (1971). Studies on the determination of the minimal inhibitory concentration of $4,4^{\prime}$-diamino-diphenylsulphone (Dapsone, DDS) against Mycobacterium leprae. Lepr. Rev. 42, 101.

Ellard, G. A. and Naylor, R. F. (1961). The absorption, metabolism and excretion of 1 -(p-dimethylaminophenyl)-3-(p-butoxyphenyl)-2-thiourea in man. A study using ${ }^{35} \mathrm{~S}$ labelled drug. Lepr. Rev. 32, 249.

Emerson, P. A. and Nicholson, J. P. (1965). The absorption of 4,4'-diisoamyloxythiocarbanilide (Isoxyl) using radioactive material (S.35 tagged). Trans 24 th Res. Conf. Pulm. Dis. p. 44. Washington: Veterans Administration Armed Forces.

Fox, W. (1971). The scope of the controlled clinical trial, illustrated by studies of pulmonary tuberculosis. Bull. Wld Hlth Org. 45, 559.

Fox, W. and Mitchison, D. A. (1975). Short course chemotherapy for pulmonary tuberculosis. Am. Rev. resp. Dis. 111, 325.

Francis, J. (1953). The distribution of sulphone in the tissues of various animals. J. Comp. Path. 63,1 .

Garrod, J. M. B . and Ellard, G. A. (1968). Appearance of resistance during prolonged treatment of leprosy with thiambutosine. Lepr. Rev. 39, 113.

Glazko, A. J., Dill, W. A., Montalbo, R. G. and Holmes, E. L. (1968). A new analytical procedure for dapsone. Application to blood-level and urinary-excretion studies in normal men. Am. J. trop. Med. Hyg. 17, 465.

Holmes, I. B. and Hilson, G. R. F. (1972). The effect of rifampicin and dapsone on experimental Mycobacterium leprae infections; minimum inhibitory concentrations and bactericidal action. J. med. Microbiol. 5, 251.

Israeli, Z. H., Cucinell, S. A., Vaught, J., Davis, E., Lesser, J. M. and Dayton, P. G. (1973). Studies of the metabolism of Dapsone in man and experimental animals: Formation of N-hydroxy metabolites. J. Pharmac. exp. Ther. 187, 138.

Keberle, H., Schmid, K. and Meyer-Brunot, H. G. (1968). The metabolic fate of Rimactane in the animal and in man. A symposium on Rimactane, Ciba. p. 20.

Levy, L. (1974). Pharmacologic studies of clofazimine. Am. J.trop. Med. Hyg. 23, 1097.

Levy, L., Shepard, C. C. and Fasal, P. (1973). Death of Myco. leprae following treatment of leprosy patients with $1500 \mathrm{mg}$ rifampicin in a single dose. Paper read at Tenth International Leprosy Congress, Bergen. 17.8.73. Abstract Int. J. Lepr. 41, 490. 
Lowe, J. (1954). The chemotherapy of leprosy. Late results of treatment with sulphone and with thiosemicarbazone. Lancet ii, 1065.

Meade, T. W., Pearson, J. M. H., Rees, R. J. W. and North, W. R. S. (1973). The epidemiology of sulphone resistant leprosy. Paper read at Tenth International Leprosy Congress, Bergen, 17.8.73. Abstract Int. J. Lepr. 41, 684.

Miller, A. B., Nunn, A. J., Robinson, D. K., Ferguson, G. C., Fox, W. and Tall, R. (1970). A second international co-operative investigation into thioacetazone side-effects. Bull. Wld Hlth Org. 43., 107.

Murray, J. F. Jr., Gordon, G. R. and Peters, J. H. (1974). Tissue levels of dapsone and monoacetyldapsone in Lewis rats receiving dietary dapsone. Proc. West Pharmac. Soc. 17, 150.

Ozawa, T., Shepard, C. C. and Karat, A. B. A. (1971). Application of spectrophotofluorometric procedures to some problems in Mycobacterium leprae infections in mice and man treated with dapsone (DDS), diacetyl-DDS (DADDS), and di-formyl-DDS (DFD). Am. J. trop. Med. Hyg. 20, 274.

Pearson, J. M. H., Pettit, J. H. and Rees, R. J. W. (1968). Studies on sulfone resistance in leprosy. 3. A case of "partial" resistance. Int. J. Lepr. 36, 171.

Peters, J. H., Gordon, G. R., Murray, J.F. Jr., Fieldsteel, A. H. and Levy, L. (1972). Minimal inhibitory concentration of dapsone for M. leprae in rats. Int. J. Lepr. 40, 467.

Pettit, J. H. S., Rees, R. J. W. and Ridley, D. S. (1966). Studies of sulfone resistance in leprosy. 1. Detection of cases. Int. J. Lepr. 34, 375 .

Quyen, L. K., Buu-Hoi, N. P. and Xuong, N. D. (1960). Résultats d'un traitement antilépreux pilote par le $4,4^{\prime}$-diethoxycarbanilide dans un hôpital du Sud Vietnam. Bull. Acad. natn. Méd. 144, 535 .

Rees, R. J. W. (1967a). Drug resistance of Mycobacterium leprae particularly to DDS. Int. J. Lepr. 35, 625.

Rees, R. J. W. (1967b). A preliminary review of the experimental evaluation of drugs for the treatment of leprosy. Trans. R. Soc. trop. Med. Hyg. 61, 581.

Rees, R.J.W., Pearson, J.M.H. and Waters, M.F.R. (1970). Experimental and clinical studies on rifampicin in the treatment of leprosy. Br. med. J. i, 89.

Russell, D. A., Peters, J. H., Vincin, D. R., Scott, G. C. and Shepard, C. C. (1973). Clinical assessment at 5 years in the acedapsone (DADDS) trial in the Karimui, New Guinea. Correlation with plasma sulphone levels. Paper read at Tenth International Leprosy Congress, Bergen, 13.8.73. Abstract Int. J. Lepr. 41, 486.

Shepard, C. C. and Chang, Y. T. (1964). Activity of antituberculosis drugs against Mycobacterium leprae. Studies with experimental infection in mouse footpads. Int. J. Lepr. 32, 260.

Shepard, C. C., Levy, L. and Fasal, P. (1969). The sensitivity to dapsone (DDS) of Mycobacterium leprae from patients with and without previous treatment. Am. J. trop. Med. Hyg. 18, 258.

Shepard, C. C., Levy, L. and Fasal, P. (1972a). The death rate of Mycobacterium leprae during treatment of lepromatous leprosy with acedapsone (DADDS). Am.J. trop. Med. Hyg. 21, 440 .

Shepard, C. C., Levy, L. and Fasal, P. (1972b). Rapid bactericidal effect of rifampicin on Mycobacterium leprae. Am. J.trop. Med. Hyg. $21,446$.

Shepard, C. C., Levy, L. and Fasal, P. (1974). Further experience with the rapid bactericidal effect of rifampicin on Mycobacterium leprae. Am. J. trop. Med. Hyg. 23, 1120.

Shepard, C. C., Walker, L. L., Van Landingham, R. M. and Redus, M. (1971). Kinetic testing of drugs against Mycobacterium leprae in mice. Activity of cephaloridine, rifampicin, streptovaricin, vadrine, and viomycin. Am. J. trop. Med. Hyg. 20,616.

Then, R. and Angehern, P. (1975). Sulphonamide-induced 'Thymineless Death' in Escherichia coli. J. Gen. Microbiol. 76, 255.

Waters, M. F. R., Rees, R. J. W., McDougall, A. C. and Weddell, A. G. M. (1974). Ten years of dapsone in lepromatous leprosy: Clinical, bacteriological and histological assessment and the finding of viable leprosy bacilli. Lepr. Rev. 45, 288.

Weddell, A. G. M., Ellard, G. A., McDougall, A. C., Allen, B. W., Gammon, P. T., King, R. C. and Rees, R. J.W. (1975). The penetration of dapsone, rifampicin, isoniazid and pyrazinamide into peripheral nerves. In press. 